\title{
FREE SPEECH AND POLITICAL EXTREMISM: HOW NASTY ARE WE FREE TO BE?*
}

I want to discuss the limits of freedom in speaking and publishing: what they are, and what they should be. I want to ask you and myself about the frontiers, the extremes, the uses of speech that seem barely tolerable, about uses of freedom that are, in fact, intolerable to many.

I am not thinking merely about controversial speech. That's easy. Or agitating speech. That's not very hard. I am thinking about speech that is nasty, vicious, wrongheaded, and downright evil or at least thought to be so. I am not sure what content or manner meets that description. We all know that when two parties are in bitter, mortal conflict, each one thinks the other is evil, nasty and morally wrong.

As an example, consider the war between Iran and Iraq recently in progress. Each party finds the other utterly vicious. But, you say, that is war! Right. We want to think about freedom within a civil society, a society divided, perhaps, even angry and bitter, but still civil. How far may speech go in such a setting? What is permissible?

Consider another example, within a civil society, closer to our target. In Miami, on Biscayne Boulevard, in March of 1986, there was a confrontation between a group of anti-Contra demonstrators, and a group of pro-Contra demonstrators - groups whose members detest and revile one another, as you know. [Note: The double negative "antiContra" sounds silly, but in this case is not readily avoidable; I use it for the sake of accuracy.] One of the pro-Contra folks was waving a plac-

\footnotetext{
* The papers in this symposium were originally presented at the first University of Miami-Southeast Banking Corporation Foundation Symposium on Ethics and Society in January 1988 directed by Professor Alan Goldman of the University of Miami. We are grateful for his assistance in arranging for the publication of these papers.
} 
ard at one of the anti-Contra speakers which read: "[So-and-so] is a bigot..." and then added more about Nicaragua. It was a nasty sign, and the police asked him to stop waving it. He replied, according to the lengthy report in The Miami Herald, "On top of that, he's an SOB" and then he added "They say in war and love everything is permitted. And this is war!"

Let's think about this situation briefly, to learn from it. We may accept the premise about war, although it may be overstated; there are laws and rules governing warfare, too. In war, let us assume, no holds are barred. But, in that conflict of demonstrators, could nastiness in speech be justified by a state of war? Surely not. We were then, and we are now, not at war. In war we shoot and kill. Here in Miami we are in a civil society, seeking to govern ourselves, although divided, with order and fairness, and aiming to live decently.

Nothing is to be gained by saying: The rules are off! No rules! That simply makes brutes of us all. In that way we return ourselves to the animal world. I remember a sort of chant I learned, long ago, from my Spanish teacher at Miami High, in which the final line (if I recall correctly) was a petition to Santa Maria, to deliver us all from the reign of the animals. The philosophically interesting and politically interesting question is: What speech is permitted when the rules are on?

Now that pro-Contra demonstrator was wrong to justify his nasty words by the claims of war. But he was not necessarily wrong in seeking to justify his words within the rules. I do not address the merits of the argument - which side is right, whether anyone in the controversy is or was a bigot or an SOB. This is not my concern here, plainly. But saying such things of another demonstrator, or of the other group (that they are bigots, etc.) - is that permissible? Or should the police have taken away his sign?

I will put my cards on the table: I think that that particular speech was within the rules. The rules permit it, the good rules of a good society, the rules that protect speech and the freedom to speak to the furthest limit in a democratic civil community.

I will defend here an old, sound, conservative proposition: in the realm of political speech, no content, no nastiness, no stupidity or evil, 
may be silenced. Even when we are convinced, to the bottom of our souls, that what they are saying is awful and ugly, we must protect their saying. That is the glory of a free society.

The argument defending this conclusion I am going to pursue with you in some detail. But I don't want to do that in the context of the pro-Contra/anti-Contra conflict. That's almost too easy, because we are all well aware that that conflict is a political one, and one on which there really are two sides, both vigorously argued. So I want to transpose the case into one that is harder, and one in which we (very probably) are all on the same political side.

In that same confrontation (according to the Miami Herald of 23 March 1986) one of the pro-Contra supporters said: "I'm Jewish, and what these people are doing is the same as if the Nazis were demonstrating in Miami Beach". And another participant also compared the anti-Contra protest to a Nazi march in a Jewish neighborhood in Miami Beach, or to a Ku Klux Klan rally in a black neighborhood.

That's an extreme comparison, perhaps, but a useful one. Let's think in those terms. We, you and I, will have no disagreement about the evils of Nazism, or the nastiness of racism. So, as an intellectual adventure with some electricity, let's ask: What limits are there on the nastiness of those nasty folks? In this matter I am as privileged as the person quoted in the demonstration; I'm Jewish too.

We Americans have some experience in these matters. Ten years ago, you will recall, in Skokie, Illinois, - also a very Jewish community, a northern suburb of Chicago - the Nazis planned a march. The Village government tried to stop them. The battle became a royal one, even reaching the United States Supreme Court. Let's think about the extremes of political speech in that context. In your minds, picture the American Nazis, jerks, square-heads, with uniforms and swastikas and placards, planning to march down Collins Avenue, or Washington Avenue, on Miami Beach, and then down Fifth St. [My parents, in their late years, lived in a condominium at the corner of Washington and Fifth. I remember my mother saying that when that building opened, a new Chapter of Haddassah came instantly into being!]

Now, many would say that such a Nazi march should not be per- 
mitted. They might say: "Look, we recognize the central importance of free speach. But free speech is like every other freedom in that it must have limits in a good society. The Nazis, saying what they say in the way they say it, exceed reasonable limits. Associating themselves with the annihilation of millions of Jews, they seek to advance their views, abrasively, in a community - Miami Beach - populated by many of the same people who had been tortured by Nazis. Some of these Jews, after narrow escape, actually sought refuge in this country, in Miami. We applaud the vigorous defense of free speech - but this is a case in which the constitutional protections of dissident opinions do not apply".

But that position is not sufficient as is stands. Certainly it is true that neither the Constitution, nor any sensible principle lying behind it, guarantees the right to say anything, anywhere, anytime. But if we are going to allow some speech to be restricted, those restrictions must be very narrowly drawn, and sustain a heavy burden of justification. So the Nazi-blockers [not "anti-Nazis" because that name would apply to many who would also protect the right of the Nazis to demonstrate] face the task of giving sound argument specifying the proper limits of free speech, limits that would be exceeded by the Nazis. I use the case of the Nazis precisely because it is as extreme as any I can imagine, and therefore the best test for the principles I shall put forward.

My enterprise, then, is to consider the limits and the arguments the Nazi-blockers put forward, and to see if we find them sound. And you will join me in this task, I trust. I will do this in six short "chapters".

\section{Chapter 1. Danger}

Grave danger is the basis of a kind of limit upon speech thought reasonable by many. You know the famous passage written by Justice Holmes in 1919: "The question in every case [he wrote] is whether the words used are used in such circumstances and are of such a nature to create a clear and present danger that they will bring about substantive evils that Congress has a right to prevent" [Schenck v. United States, 249 US 47 at 52]. Now if the Nazis March on Collins Avenue the dangers are patently clear, and arise immediately as they march. So would not Justice Holmes's illustration apply? He continued: “The most stringent 
protection of free speech would not protect a man in falsely shouting fire in a theater, and causing a panic". Don't Nazis marching in Miami Beach, in effect, shout fire in a theater? If their speech is irresponsible, why must we permit it? Neither the shouter in the theater, nor the Nazi on Collins Avenue (says the Nazi-blocker) is entitled to the constitutional protection of free speech.

But the analogy with the theater is in fact not good at all. Whoever shouts fire in a theater is certainly not entitled to protection on grounds of free speech. But the circumstances of a Nazi demonstration differ from those in a theater in three fundamental respects:

a) The theater audience is captive, subjected against its will to the shout and the sequel. Not so any gathering for a Nazi parade. Those angered or offended are free to stay away, or to leave; they need have nothing to do with it. The panic in the theater traps and injures those who had come for reasons entirely unrelated to the shout. What is reasonably said in a theater depends, of course, upon what properly goes on there - an expectation reasonably imposed upon speech in the classroom as well. The shouted false alarm is not essentially speech in the theater at all; it is a warning of danger fraudulently given, no different from the fraudulent ringing of a fire alarm bell. But concerning the audience any Nazi march may draw, all of this simply cannot be said.

b) A shouted warning, or false alarm, permits no discussion. It is not the expression of opinion, but the signal for flight, giving no opportunity for reasoned reply. The other day, in Ann Arbor, some criminal fool released a tear gas cannister in a theater! The audience was presented with inescapable threat; it had no options. But we who find the Nazis hateful do have options; the Nazi demonstration may be answered with a counter-demonstration, as an anti-Contra demonstration may be answered with a pro-Contra demonstration. What is evil may be exposed, refuted, in print or by voice, then or later. Demonstrations by bigots, Nazis or others, cannot threaten immediate calamity at all comparable to a false alarm in a crowded theater. 
c) The shouted alarm of fire is, by hypothesis, false. We would think very differently of an honest warning. No doubt Nazi views are also false - but being right is not a condition on which permission to demonstrate may be premised. If it were, who will decide who is right enough to speak?

So true enough, there are words in some special circumstances which, because of the grave danger they present, cannot claim free speech protection - like the shouting of "Fire!" falsely in a theater. But a political demonstration, in a park or on a major avenue, is nothing like that.

\section{Chapter 2. Incitement to Riot}

"But [the Nazi-blocker rejoins] you underestimate the seriousness of the threat this demonstration would immediately create. If the Nazis march with swastikas and brown shirts on Miami Beach they will almost certainly provoke a riot. Incitement to riot is a crime. When it is deliberate as in the case we envisage, when its violent consequences are highly probable and fully anticipated, such incitement cannot be defended as mere speech. It is conduct designed to breach the public peace, using the First Amendment as a shield. Citizens of Miami Beach have the right, even the duty, to protect themselves from that despicable design".

This argument is dangerous. It is often heard, but it seriously misapprehends the concept of "incitement to riot". That a message or a symbol excites an audience to furious antagonism gives no evidence whatever of criminal incitement. That crime consists in urging upon one's audience the commission of some unlawful act in a context in which it is probable that some in the audience will do what is being urged. Even then the speaker will not normally be guilty of criminal incitement unless persons in his audience do in fact engage in the unlawful conduct he urged upon them. Nothing like these conditions are present in the case of a Nazi march in Miami Beach, or an anti-Contra demonstration in Miami. In such demonstrations it is usual that no specific acts are urged at all, and Nazis are very careful never to urge illegal acts. They say things like: "Jews Not Wanted Here!" or, "White Power!" or, "America for the White Man!" Some in their 
audience may then break the law by attacking not the Jews but the Nazis themselves - but those whose symbols provoked their fury cannot be criminally responsible for that misconduct.

Incitement must be (and in the law it is) very narrowly delineated. When overt unlawful deeds are committed as a direct consequence of agitating speech, that speech becomes a part of the crime - as the planning of a robbery becomes part of the robbery itself; and persons whose inflammatory words lead to the very disorder they propose may be similarly culpable as part of the deliberate creators of that disorder. But Nazis, in Miami Beach, where no one in the audience will be inclined to do anything they may urge, could never be guilty of inciting to riot.

\section{Chapter 3. Incitement and the General Intent to Breach the Peace}

"You may be technically correct [the Nazi-blocker answers] about the requirements for that criminal charge, but you are blinded by technicalities. The Nazis delight in creating fright and havoc among Jews. In this country, in recent years, their demonstrations have several times actually resulted in riot. Nazis understand full well how maddening their symbols are to their intended victims; they plan that abrasion. It is a good principle in law that one may reasonably be held to intend the natural and anticipated consequences of one's acts. True, the riot will not be caused by an audience that complies with their urgings, so they may be innocent of some technical crime of incitement. They will nevertheless be guilty of engaging deliberately in conduct designed to infuriate, and calculated to result in a wholesale breach of the public peace. Incitement in that more general sense is what we have the right to protect ourselves against".

This argument has much appeal - but I contend that it is profoundly mistaken. The citizens of Miami Beach, or of Miami or of Skokie, may not silence infuriating speakers because of the response expected to their words. If they may silence speakers on that ground, no truly controversial position on an incendiary topic could be freely presented there. For in that case, whencver it could be shown that the probable reaction would be intemperate or disorderly, the advocacy of an unpopular position would have to be forbidden. Thus tying the per- 
missibility of controversial speech to its expected reception establishes what has been called "the heckler's veto". A decent society, one that honors freedom concretely, cannot authorize that veto; it is those who respond illegally and violently who must be restrained.

Very unpopular causes may be as freely advocated under our Constitution as those in popular favor. Political advocates at the extremes, radical or reactionary, wise or crazy, will commonly meet with an angry and unruly reception. Communists, pacifists, Nazis, hawks and doves - those at the extremes - will be forever in need of defense. Their freedom is in our interest not only because our side may one day be threatened with similar response, but because rational judgment upon any position requires that that position be heard. Some lessons must be continually relearned, even by those who once taught them. If Nazis are not free to demonstrate because their Jewish audience will be hostile, the Jews will not be free to demonstrate when their Arab audience [and in Detroit we have a very large Arab-American community] promises equal hostility. When demonstrations to which sufficient anger may be threatened are not allowed, the hecklers have been given the veto - and then they may exercise it no matter what the content of their views.

This issue was fully tested, in our country, in a most interesting actual case. In Chicago, in 1949, a passionate message of racial hatred was delivered (by a Catholic priest under suspension) to a sizable audience in a large hall. Outside, a cordon of police struggled to control the infuriated counter-demonstrators, while Father Terminiello completed his speech. He was later convicted of creating a breach of the peace - a breach actually created not by him or his followers but by persons outside the hall, so maddened by his bigotry as to throw bottles and bricks at the windows as he spoke. Is Terminiello to be punished for speaking so? The judge in the trial court had instructed the jury that the words "breach of the peace" include speech that "stirs the public to anger, invites dispute, brings about a condition of unrest, or creates a disturbance..." That, said the Supreme Court of the United States, was grave error. Justice Douglas wrote the majority opinion. He said: "[One] function of free speech under our system of government is to invite dispute. It may indeed best serve its high purpose when it 
induces a condition of unrest, creates dissatisfaction with conditions as they are, or even stirs people to anger. Speech is often provocative and challenging. It may strike at prejudices and preconceptions and have profound unsettling effects as it presses for acceptance of an idea. That is why freedom of speech, though not absolute, ... is nevertheless protected against censorship or punishment, unless shown likely to produce a clear and present danger of a serious substantive evil that rises far above public inconvenience, annoyance, or unrest" [Terminiello $v$. City of Chicago, 337 US 1, at 4, 1949].

Ironically, the right of a racist to speak thus defended became a bulwark for the freedom of those they reviled. Years later, civil rights activists, convicted because of the tumultuous responses of their hostile audiences, had their convictions reversed also by the Supreme Court, relying on the precedent set in the Terminiello decision.

The pendulum swings for strong and weak alike. In Miami, in 1986, it was the anti-Contra demonstrators who were infuriating to the majority, and highly provocative. But in Cambridge, Massachusetts, in 1987 , it was the pro-Contra speakers who were the object of a maddened attack. I have clipped a photograph from The New York Times of a hall at Harvard University, in which a Contra leader, Adolpho Calero, was speaking; an anti-Contra demonstrator, believing him a devil, is attacking the speaker physically to silence him [NY Times 4 Oct 87]. Shall we silence Calero for a breach of the peace, or collar that young man who does not grasp the point that disagreement, even when bitter, does not justify suppression? Plainly he must learn, and we must never forget, that even in the most hostile territory the right to political agitation for all parties (in our country) has been and will be secured.

And those who would forbid a demonstration before it begins have a much weaker case even than those who would convict Calero, or Terminiello. For in those cases, the attacks did take place; in the case of the envisioned march on Miami Beach, we cannot be certain that incivility and disorder will rule the day. You may recall that in the famous Pentagon Papers case, when the United States Government argued that the publication of those papers in the New York Times would lead to loss of life in Southeast Asia, the Supreme Court held 
that such an argument (even if the publication were ultimately found unlawful) may not serve as a ground for the suppression of the publication in advance. If that is true for stolen government papers, is it not all the more true in defense of speech in a public, political demonstration?

\section{Chapter 4. Fighting Words}

"Well [says the Nazi-blocker] it should be grounds for suppression, even if it isn't, if the speech in question has a very high probability of provoking violence. Of course we can't know with absolute certainty that a riot will ensue if the Nazis march with swastikas in Miami Beach, but we can be pretty confident when we predict it. Some words and symbols, by their plain meaning in known contexts, are so provocative as to cause decent and reasonable people to respond by fighting. Speech like that [they conclude] is rightly forbidden.

"And in this [they continue] the Supreme Court is on our side. Some years ago, in New Hampshire, a Jehovah's Witness named Chaplinsky was convicted, when stopped from preaching in the street, for shouting at a policemen thus: 'You are a goddamned racketeer [and] a damned fascist and the whole government of Rochester $[\mathrm{NH}]$ are fascists or agents of fascists'. He claimed freedom of speech as his shield, but the Supreme Court held that some utterances are not entitled to normal protection. They wrote: ' $\mathrm{It}]$ is well understood that the right of free speech is not absolute at all times and under all circumstances. There are certain well-defined and narrowly limited classes of speech, the prevention and punishment of which have never been thought to raise any constitutional problem. These include the lewd and obscene, the profane, the libelous, and the insulting or "fighting words" - those which by their very utterance inflict injury or tend to incite an immediate breach of the peace'" [Chaplinsky v. New Hampshire, 315 US 568 , at 572,1942$]$.

So the Nazi-blocker concludes: "Not protecting 'fighting words' as though they were normal political controversy is plain good sense. In a community where live thousands of survivors of Nazi death camps, an aggressive Nazi demonstration is surely speech which, by its very utterance, inflicts injury and tends to incite an immediate breach of the peace". 
But this argument simply does not apply to the case of the political demonstration here being discussed.

First, the doctrine, that words may be treated as equivalent to the first blows in a fight is highly suspect, and it is a view now almost completely abandoned in the courts. What words under what circumstances may be treated so must forever be uncertain and disputable. Words that infuriate you may merely amuse me. Words can hurt, surely, - but there is a great difference between verbal hurts and physical blows. That is why, honoring freedom generally, we place freedom of speech in the most protected of arenas. If words that sometimes provoke a fight are punished because of that danger, the uncertainty about which words may have that consequence must chill all debate, hedge all robust speaking in a vigorous contest. Words are not literal blows; the metaphor must not be allowed to confuse; the theory that, in a civil society, nasty words may justify physical retaliation is simply not tenable.

But, second, even if the "fighting words" doctrine had some appropriate application in some contexts, it would have to be so narrowly restricted to special circumstances as to have no bearing on a proposed demonstration by a political sect or party. It could, at best, be applied only to utterances by a specific person to the face of another, being defamatory in the extreme. Demonstrations before a general public by the KKK, or the Black Panthers, or the anti-Contras, or the proContras - are not one-to-one confrontations however maddening we may think their point.

Third, the doctrine could apply, if ever, only after those personal insults had been hurled, and a retaliatory blow struck - never as the ground for forbidding a demonstration in advance.

And finally, if the doctrine were ever applicable, it would certainly be restricted to cases of grave, personal offense; it has no application where the cause of agitation, however bitter, is political. This "fighting words" gambit cannot succeed.

\section{Chaprer 5. Obscenity}

Finally, then, the Nazi-blocker must admit that it is not really harm to some persons that motivates him, or danger to all, or incitement 
to riot, or fighting words, or any such concern. It is the plain evil of those Nazi views - the racism and anti-semitism and general stupidity and bigotry - that he thinks deserves to be silenced. When all the other arguments have failed he comes in the end to question the principle of free speech itself, asking, in effect, whether that principle really does oblige us to protect all content, however damnable. This is his last resort.

"Some speech content [he argues at last] - speech utterly without redeeming social value - is not and ought not be protected by the First Amendment. Obscenity, of course, is normally associated with sexually explicit matter. But its essential, nonsexual characteristics are two: a) it is intolerably offensive in some settings; and b) it is totally worthless. Whatever may be permitted behind closed doors, there are some forms of language, and pictures, and acts - perverted behaviors, sexual intercourse - that are not permitted in public places. That prohibition is based on the recognition that thrusting specific content of that kind upon an unwilling audience in a public place is a gross imposition, and a cause of offense against which that audience, and all of us, have a right to be protected. Such obscene matter does not contribute in any way to the public forum. It is barren of ideas, and not at all the kind of stuff - opinion, argument, information - that the Supreme Court has insisted must be protected by our Constitution.

"Some political garbage - like that of the Nazis and the KKK, although not in the same way carnal, is just like that. Citizens of a decent community have a right to be shielded from it in precisely that spirit. Indeed, lascivious acts or pictures are offensive, but not nearly as offensive as some irrational racism, or anti-semitism. So we contend [the Nazi-blocker continues] that in a wide but accurate sense of the term, hate-mongering like that of the Nazis is obscene. As that category is used now in the law, the term might not apply. But it is still not an unreasonable stretch of language, or of concept, to prohibit Nazi speech on the same fundamental grounds".

And that is what it comes to, that is what all censorship comes to, in the end: some content is thought so very bad that it must not be heard or seen. I call this argument "the outrage override". With this we get to the root of the conflict between the blocker and the civil libertarian. 
The blocker believes in his heart that some things may be suppressed because the content of the views expressed are simply intolerable, "beyond the pale". The libertarian believes in his heart that giving to any the power to silence what they do not think it worthy to hear is more intolerable still. That is why Nazis and other racists provide a good illustrative case. Their views are thought manifestly worthless, and that is not in dispute - but they are laden with ideas. Of course some of those ideas are despicable, but sometimes just for that reason they are meaningful. No segment of society, I argue, is entitled to decide for the rest of us that some ideas are so lacking in worthy content that we will have no opportunity to evaluate them for ourselves.

Even where the matter in question has no political content, and is sexually explicit, and is known to give offense to some, we protect the freedom of others to see or hear it by obliging those who are offended to shield themselves by turning it off, or turning away, or walking away. That was the very issue faced by the Supreme Court of the United States in another case - a Florida case, in fact [Erznoznick v. City of Jacksonville, 422 US 205 at 207, 1975]. The objectionable matter in question appeared on a drive-in movie screen, showing X-rated films, and viewable from a road in the distance. But when it is possible for a viewer or hearer to turn away, said the Court, his being offended when he does not do so will not serve to cancel the rights of others to speak, or to listen or to watch.

Justice Powell, recently retired from the Court, wrote the majority opinion in Erznoznick, saying, in part: "When the government, acting as censor, undertakes selectively to shield the public from some kinds of speech on the ground that they are more offensive than others, the First Amendment strictly limits its power... [R]estrictions have been upheld only when the speaker intrudes upon the privacy of the home... or the degree of captivity [of the audience] makes it impractical for the unwilling viewer or auditor to avoid exposure" (p. 209).

And sometimes the garbage is inextricably mixed with other stuff that deserves a hearing. In yet another case, in which a young man in a courthouse wearing a jacket with words on it ["Fuck the draft"] that I find uncomfortable to repeat in public, but words having a political 
message too, was arrested for obscene display, the Supreme Court vindicated him in the end:

The ability of Government, consonant with the Constitution, to shut off discourse solely to protect others from hearing it is ... dependent upon a showing that substantial privacy interests are being invaded in an essentially intolerable manner. Any broader view of this authority would effectively empower a majority to silence dissidents simply as a matter of personal predilections [Cohen v. California 403 US 15, at $21 ; 1971]$.

So we have to ask: is the extreme political speech in question (say, the Nazi garbage) an invasion of the privacy of the citizens? Generally it is not. A Nazi march down Collins Avenue - or one by the antiContras on Biscayne Blvd. - would surely not be. Streets and parks are the common and proper places for for political assembly. To some degree we cannot avoid encountering what happens in such places but we do not have to stay, and we cannot expect to be insulated by law from all that we find intensely objectionable.

Justice Powell [in Erznoznick] continues:

The plain, if at time disquieting truth is that in our pluralistic society, constantly proliferating new and ingenious forms of expression, "we are inescapably captive audiences for many purposes." ... Much that we encounter offends our aesthetic, if not our political and moral sensibilities. Nevertheless, the Constitution does not permit government to decide which types of otherwise protected speech are sufficiently offensive to require protection for the unwilling listener or viewer. Rather, absent the narrow circumstances described above [in which exposure is entirely impossible to avoid] the burden normally falls upon the viewer to 'avoid further bombardment of his sensibilities simply by averting his eyes' [422 US 210.] .... The limited privacy interests of persons on the public streets cannot justify ... censorship of otherwise protected speech on the basis of its content.

"Well, [comes the last try from the Nazi-blocker] is this Nazi garbage 'otherwise protected speech'? Have we not agreed that it is utterly worthless, and offensive, and is it therefore not like hard-core obscenity, unentitled to protection? If so, we are justified in prohibiting it".

But it is not, not at all. The right of the public to see and hear Nazis, or Communists, or Contras, or anti-Contras, or any political view, however extreme, is at least as compelling as the right to read risque 
literature or look at bare breasts and buttocks on the screen. Even with respect to pornography, simply because some materials lack redeeming social value - whatever that is - does not justify prohibition. For material having any political content whatever, that argument could not possibly apply, and could not possibly be applied fairly.

\section{Chapter 6. Conclusion}

What then shall we conclude about political extremism and free speech? Are there any restrictions, of any kind, that may be applied to such speaking? Of course there are! The speaking that is bridled with criminal acts does become part of those later deeds. And, apart from criminality, there are reasonable restrictions that may be enforced upon the manner of speaking, and the place of it, and the time of it. We may permit rallies in the parks, and yet reserve some quiet arboretum as a place where no political demonstrations may be held. We may respect political demonstrations on downtown streets - and yet hold that, during the rush hours, political demonstrations will create more inconvenience than is tolerable. Or we may, as a community, protect residential streets from noisy demonstrations. The places may be restricted, the times may be restricted - and the manner too, eliminating, say, all electronic megaphones and super-noisy amplification. We may, within the rules, impose such regulations - but, and this is the key, we may not do so selectively. The restriction of manner or place that applies to one view applies to all. It may be unlawful to post stickers on public walls - but that applies to all stickers, not just those of the unfavored minority. And what we permit for the politics in wide favor say, a march on Main Street - we must permit for the nastiest of the unfavored. By content we must, in a free society, make no exceptions. Freedom is not merely for those we can tolerate; it is for all.

Finally, then, please note: Robust, wide open political debate, uninhibited political debate, in parks and streets and lecture halls, is going to rouse anger, and give offense. Some public offensiveness, and some private distress, will be an inevitable cost of freedom. That is what a free, democratic society requires. It is not simply the kooks whom we protect, but ourselves. Citizens who would govern themselves - we - 
have the right to hear every opinion on our public business. The Nazis may be crazy, or vicious, but that does not cancel our need to pass judgment upon them; therefore the opportunity to hear them must be protected, partly in their interest, but mainly in ours.

And we cannot make exceptions for the specially nasty bits. Some say: "OK then, let them speak - but not with their infernal Swastika!" But if the Swastika is too offensive for some to tolerate today, the Star of David will be claimed equally intolerable by others tomorrow.

So, I say, the Nazis have the same right to sing the "Hort Wessel Lied", that others have to sing the "Internationale", and still others "We Shall Overcome". To the claim that some stuff is just too nasty to permit, I answer: no degree of nastiness can justify silencing speech in a free society.

Even on Miami Beach for the Nazis? And even in Miami for the anti-Contras? Yes, the effectiveness of political protest often depends critically upon the symbolic use of location. When the Nazis planned to demonstrate in Skokie ten years ago, whatever we may think of them, that location, being heavily Jewish, was part of their point. Civil rights demonstrators, as part of their point often carried their moral convictions, very offensive to the segregationist majority, to the heart of Jim Crow country - to Selma, Alabama, and Philadelphia, Mississippi. Blacks who demonstrate for fair housing opportunities often do so in the heart of middle-class suburban communities that would exclude them. The Nazis carry signs reading "White Power". If we do not permit them to do that in black neighborhoods, how can we justify Black Panthers carrying signs saying "Black Power" in white neighborhoods?

But the civil rights marchers carried a message of human equality and decency; the swastika is the symbol of unspeakable indecency. Yes. But that judgment of contents cannot be made antecedently, and can have no bearing upon the right to speak publicly. Our best hope that sound judgment will be passed upon nasty political views lies in the freedom of all to hear them, and the freedom of all to speak and write in reply.

I conclude: We learn from the extreme case. The Nazis, by presenting a case about as extreme as any we can conjure up, provide us with 
an instructive test of our own principles. These are powerful principles, and sound ones; they are a tribute to our own civility, and - if I may be permitted to end on a slightly corny note - one of the most deeply satisfying marks of our own national culture, of which I am very proud.

Dept. of Philosophy,

University of Michigan,

Ann Arbor, MI 48109,

U.S.A. 